\title{
Synthesis, Characterization and Stability of the Polymeric Complexes of Zinc (II), Cadmium (II) and Cerium (III) with 1,4-bis (2'-carboxyphenyla- zomethine) phenylene
}

\author{
M.H. Moustafa ${ }^{\#}$ and M.T. Abd-Allah \\ Department of Chemistry, Faculty of Science, Al-Azhar \\ University, Assiut Branch, Assiut, Egypt .
}

\begin{abstract}
TTHE FORMATION and stability of binary $\mathrm{Zn}^{2+}, \mathrm{Cd}^{2+}$ and $\mathrm{Ce}^{3+}$ 1 complexes with 1,4-bis(2-carboxyphenylazomethine)phenylene (BCPAP) were studied by potentiometric $\mathrm{pH}$-titrations in $50 \%$ (v/v) 1,4 dioxane-water medium $\left[\mathrm{I}=0.1 \mathrm{M} \mathrm{KNO}_{3}\right], 25^{\circ} \mathrm{C}$. Under uniform conditions the dissociation constants of the ligand BCPAP have also been examined. The potentiometric data showed that the metal contents in all complexes are consistent with 1:1 metal: ligand stoichiometry. From the formation curves the stepwise stability constants of binary chelates were determined and the optimal $\mathrm{pH}$ conditions for preparing the solid complexes were specified. The synthesized complexes were characterized using elemental analysis, infrared and electronic spectra. The reaction of the bis-bidentate ligand (1,4-bis (2'-carboxyphenylazomethine)phenylene) BCPAP with each of $\mathrm{Zn}^{2+}, \mathrm{Cd}^{2+}$ and $\mathrm{Ce}^{3+}$ gives coordination polymers. Thermal stabilities of the various coordination polymers were studied. The isolated coordination polymers were investigated by differential scanning calorimetry (DSC) to determine the glass transition temperature (Tg). The obtained $\mathrm{Tg}$ and DSC data, showed the formation of one kind of coordination polymers (homo-coordination polymers). The conductivity of the polychelates were measured both from the solution and electrode side. The surfaces of the samples were examined by scanning electron microscopy (SEM).
\end{abstract}

Keywords: Polychelates, Zinc, Cadmium and cerium, Schiff base, Synthesis, Characterization, Potentiometric study and SEM.

Coordination polymers are now of great interest ${ }^{(1-6)}$. The first example of the coordination polymer was reported by Arimato et $a l^{(5)}$. The formation of chelates has been widely used for concentration, separation and extraction of metal ions ${ }^{(7-9)}$. The addition of metal ions to the polymers considerably improves the ir mechanical properties and thermostability. Many synthetic polymer-metal complexes exhibit high catalytic activity resembling the action of metal enzymes ${ }^{(10-12)}$. Organometalic and inorganic transition-metal compounds have been used widely as flame retardants and smoke suppressants, dramatically increasing the resistance of various polymers to ignition and burning ${ }^{(13)}$. Much work has been done on the preparation of polychelates derived from poly Schiff bases $^{(14-18)}$. Abd-El-Aziz ${ }^{(19-23)}$ and other authors ${ }^{(24-27)}$ have presented several

"E- mail: mahhassan1959 @ yahoo. com. 
reviews on the synthesis and properties of metal containing and coordination polymers. Literature revealed that work on the coordination polymers of Schiff base ligands presently under investigation has not been reported. Therefore, it was of interest to study the polymers of the Schiff base prepared from terephthaldehyde and anthranilic acid, because of their strong tendency to coordinate with the metal ions. Potentiometry, being the classical and suitable method was used to search for the true equilibria, composition and the stability of the complex species in solution. This technique was used for determination of the stability of coordination polymers ${ }^{(28,29)}$. Spectroscopic ${ }^{(30)}$, fluorescence spectra ${ }^{(31)}, \mathrm{X}-$ ray analysis ${ }^{(32)}$ ionic conductivity ${ }^{(33)}$, $\mathrm{pH}$-effects on the complex formation ${ }^{(34)}$, thermogravimetry ${ }^{(35)} \ldots$, etc., have been used for the characterization of the coordination polymers and the system is apparently well known. The present paper describes the optimization of the conditions for complexation reactions of 1,4-bis(2`-carboxyphenylazomethine)phenylene (BCPAP) towards $\mathrm{Zn}(\mathrm{II}), \mathrm{Cd}(\mathrm{II})$ and $\mathrm{Ce}(\mathrm{III})$ ions. The optimal $\mathrm{pH}$ values for the formation of the polymers were found from potentiometric titrations ${ }^{(36,37)}$. The $\mathrm{pH}$ titration technique of Irving and Rossotti ${ }^{(38)}$ was employed in this study. The measurements were carried out at $25^{\circ} \mathrm{C}$, ionic strength of $0.1 \mathrm{~mol} \mathrm{dm}{ }^{-3}\left(\mathrm{KNO}_{3}\right)$ in $50 \%(\mathrm{v} / \mathrm{v})$ dioxane-water solution. The Schiff base acts as a tetradentate ligand bonding through the oxygen and nitrogen atoms. After the resulting coordination polymers were characterized, physical properties such as viscosity, solubility and electrical conductivity were also studied. High glass transition temperature indicated that the complexes are chain polymers. Electrical conductivity measurements proved that the complexes are non-conducting polymers.

\title{
Materials
}

\section{Experimental}

All chemicals were Analar pure grade. The terephthaldehyde and anthranilic acids used for preparation of the ligand 1,4-bis(2-carboxyphenylazomethine) phenylene (BCPAP) were purchased from Sigma-Aldrich Chemicals Co., USA and were used as received. Different metal salts: zinc nitrate, cadmium nitrate tetrahydrate and cerium nitrate hexahydrate were from Merck (Germany), $\mathrm{HNO}_{3}$, potassium nitrate, potassium hydroxide, potassium hydrophethalate, Borax, 1,4 dioxane, dimethylsulfoxide (DMSO) and dimethylformamide (DMF) of Analar products were obtained from Sigma- Aldrich Chem. Co., USA.

\begin{abstract}
Apparatus
$\mathrm{pH}$ measurements were carried out using a Corning $215 \mathrm{pH}$ meter with a combined glass electrode. The glass electrode was calibrated before each titration with two Merck standard buffer solutions, first with the $\mathrm{pH} 7.0$ followed by a $\mathrm{pH} 4.0$ at $25^{\circ} \mathrm{C}$ by coupling the titration cell with a thermostatic bath set at this temperature. The elemental analysis made on a Perkin-Elmer $240 \mathrm{C}$ instrument. The electronic spectra of DMF solutions of the ligand (BCPAP) and its different metal complexes were recorded on a Perkin-Elmer (Lambda 35) computerized spectrophotometer equipped with $1 \mathrm{~cm}$ matched quartz cells. A Fourier transforms Infrared spectrometer (FT-IR) analysis in the region
\end{abstract}

Egypt. J. Chem. 54, No. 5 (2011) 
400-4000 $\mathrm{cm}^{-1}$ was carried with Jasko 480 spectrometer using potassium bromide disk technique. NMR spectra were recorded in $\mathrm{CDCl}_{3}$ on Varian EM$360 \mathrm{~L}, 60 \mathrm{MH}_{\mathrm{Z}}$ NMR spectrometer and JEOL FX 90 Q Fourier transform NMR. Thermogravimetric analysis TG and differential scanning calorimeter DSC were carried out with a Schimadzu Thermal Analyzer $50 \mathrm{H}$ at heating rate of $10^{\circ} \mathrm{C} / \mathrm{min}$ in nitrogen atmosphere up to $750^{\circ} \mathrm{C}$. The solubility of polymers was determined using 0.01 gram in $3-5 \mathrm{ml}$ of solvent at room temperature. The inherent viscosities of the polymers solutions $(0.5 \% \mathrm{w} / \mathrm{v})$ in DMF were determined at $30^{\circ} \mathrm{C}$ using Ubbelohde Suspended Level Viscometer. Conductivities were measured at $25^{\circ} \mathrm{C}$ using HIOKI 3532 - 50 LCR Hi TESTER computerized electrometer as pellets between two standard graphite electrodes and were measured at $25^{\circ} \mathrm{C}$ in solutions using JENWAY 4320 conductivity meter. The isolated polymer systems were investigated by the scanning electron microscopy (SEM) with a JEOL JSM 5400.

\section{Synthesis of the Schiff base ligand (BCPAP)}

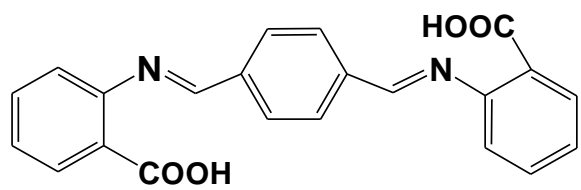

(BCPAP)

Preparation of the Schiff base ligand (BCPAP) has previously been reported $^{(39)}$.

NMR spectrum in DMSO solvent of BCPAP $\left(\mathrm{C}_{22} \mathrm{H}_{16} \mathrm{~N}_{2} \mathrm{O}_{4}\right)$ showed signals at: $\delta=10.1(2 \mathrm{H}, \mathrm{OH}$ carboxylic $)$

$=8.037-8.8132(2 \mathrm{H}, \mathrm{N}$; disappeared by $\mathrm{D} 2 \mathrm{O})$

$=6.389-7.782(4 \mathrm{H} ; 7,8,9110 \mathrm{Ar}$. ring $)$

$=2.501-3.430(2 \mathrm{H}, \mathrm{CH})$

Mass spectrum (Fig. 1) exhibited a base peak m/z; 372, 100\%FS.

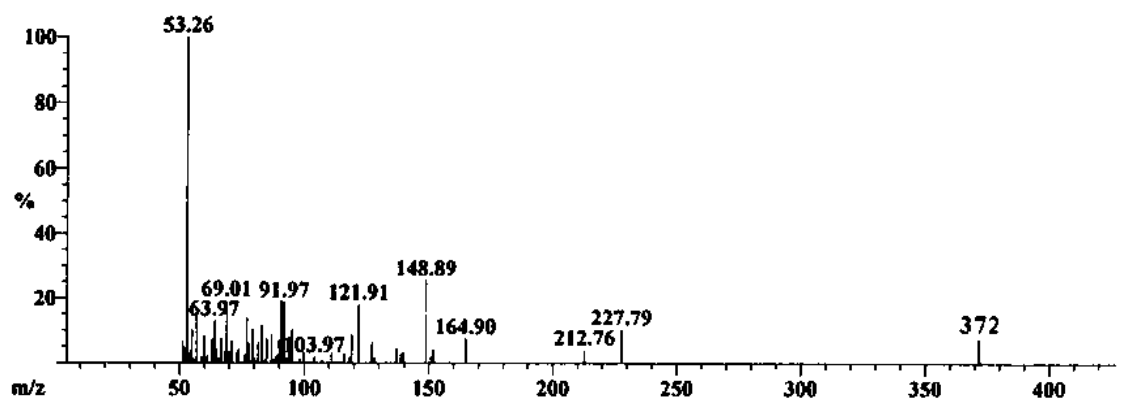

Fig. 1. Mass spectra of 1,4-bis(2 '-carboxyphenylmethine)(BCPAP). 


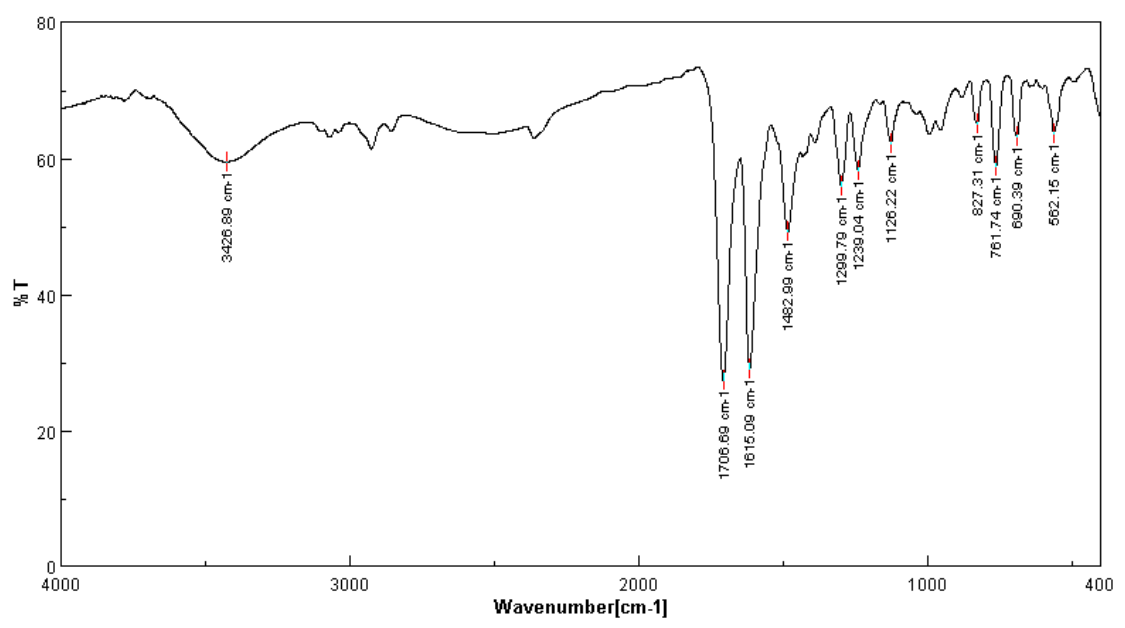

Fig. 2. FTIR absorption spectrum of BCPAP.

Syntheses of $\mathrm{Zn}(I I), C d(I I)$ and $C e(I I I)-(B C P A P)$ binary system

All the coordination complexes were prepared by mixing a suitable aliquot of metal salt containing $2.0 \mathrm{mmol}$ in of doubly distilled water with a equimolar dioxane solution of the ligand 1,4-bis(2-carboxyphenylazomethine) phenylene (BCPAP) and the $\mathrm{pH}$ value was adjusted at 6.9, 7.9 and 6.5 for $\mathrm{Zn}(\mathrm{II}), \mathrm{Cd}(\mathrm{II})$ and $\mathrm{Ce}(\mathrm{III})$ complexes, respectively by adding aqueous potassium hydroxide. Every mixture was stirred for two hours under reflux with heating on a water bath at a constant temperature of $70^{\circ} \mathrm{C}$ then concentrated by evaporation to its half volume and left to cool to room temperature overnight. Each complex was filtered off on a water pump and the obtained metal chelates were washed several times with doubly distilled water, $\mathrm{Et}_{2} \mathrm{O}$, and ethanol and finally dried in vacuum over $\mathrm{P}_{4} \mathrm{O}_{10}$.

\section{Potentiometric titrations}

Dioxane and doubly distilled water were used for the preparation of the solutions. Potassium nitrate $(1.0 \mathrm{M})$ and standard solutions $(0.01 \mathrm{M})$ of potassium hydroxide and nitric acid were prepared. Standard stock solutions of $\mathrm{Zn}(\mathrm{II}), \mathrm{Cd}(\mathrm{II})$ or $\mathrm{Ce}(\mathrm{II}) 0.02 \mathrm{M}$ were prepared ${ }^{(40)}$. Each solution was diluted so as to prepare the standard working solution. The ligand BCPAP solution was prepared in dioxane, ligand and the metal salt concentration was $2.5 \times 10^{-3} \mathrm{M}$. The potentiometric equilibrium measurements were made on $5.00 \mathrm{~cm}^{3}$ of the ligand solutions diluted to a final volume of $50.00 \mathrm{~cm}^{3}$, in the absence of metal ion for which the $\mathrm{C}_{\mathrm{M}}: \mathrm{C}_{\mathrm{L}}$ ratios were $1: 1$ and $1: 2$ in $50 \%(\mathrm{v} / \mathrm{v})$ dioxane-water solution, at $25^{\circ} \mathrm{C}$ and the ionic strength was adjusted with $0.1 \mathrm{~mol} \mathrm{dm}^{-3}\left(\mathrm{KNO}_{3}\right)$ in each case. A minimum of three replicates was made. The $\mathrm{pH}$ titration technique of Irving and Rossotti ${ }^{(38)}$ was applied. The $\mathrm{pH}$ values in the partially aqueous solutions were corrected by making use of the equation as described previously ${ }^{(41)}$. All the dissociation and the complex formation constants were determined using the

Egypt. J. Chem. 54, No. 5 (2011) 
SUPERQUAD program ${ }^{(42)}$. The program has been used to calculate acidity constants in systems previously studied ${ }^{(43-45)}$.

\section{Results and Discussion}

\section{Potentiometric study}

Proton-ligand dissociation constants

The aced-base equilibria of the ligand 1,4-bis(2`-carboxyphenylazomethine) phenylene (BCPAP) have been investigated by using potentiometric measurements in $50 \%$ (v/v) 1,4 dioxane-water medium $\left[\mathrm{I}=0.1 \mathrm{M} \mathrm{KNO}{ }_{3}\right], 25^{\circ} \mathrm{C}$. The following values of dissociation constants of BCPAP have been found by potentiometry: $\mathrm{pK}_{\mathrm{a} 1}=5.05 \pm 0.02$ and $\mathrm{pK}_{\mathrm{a} 2}=6.125 \pm 0.02$. Dissociation of carboxyl protons begins at $\mathrm{pH} \sim 3.10$; over $\mathrm{pH} 6.50$ the anion (BCPAP) $)^{2-}$ is prevalent. Dissociation of the first carboxyl proton and the formation of a probable anion (BCPAP-H) $)^{-}$originates from $\mathrm{pH} 3.10$ - 5.65 and a further carboxyl proton dissociates at $\mathrm{pH} \geq 5.70$ forming the divalent anions (BCPAP $)^{2-}$. It seemed of importance to characterize the acid-base equilibria of BCPAP under our experimental conditions. In the $\mathrm{pH}$ range investigated $\geq 3.5 \leq 11.5$ two carboxyl protons are dissociated. The species of $\left(\mathrm{BCPAP}-\mathrm{H}_{2}\right)$ undergoes ionization on increasing the $\mathrm{pH}$ of solution according to the following protonation equilibria:

$$
\begin{aligned}
& \left(\mathrm{BCPAP}-\mathrm{H}_{2}\right)=(\text { BCPAP-H})^{-}+\mathrm{H}^{+} \quad(\mathrm{pH} 3.10-5.65) \ldots \ldots \ldots \ldots \ldots \text { 1a }
\end{aligned}
$$

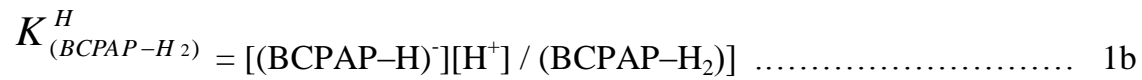

$$
\begin{aligned}
& (\mathrm{BCPAP}-\mathrm{H})^{-}=(\mathrm{BCPAP})^{2-}+\mathrm{H}^{+} \quad(\mathrm{pH} 5.70-6.95) \ldots \ldots \ldots \ldots . .2 \mathrm{a}
\end{aligned}
$$

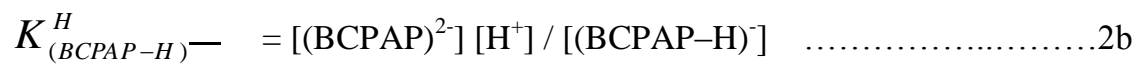

The proton - ligand dissociation constants as depicted from the titration curves were used for calculating stability constants of the metal ion complexes.

\section{Metal - ligand stability constants}

From the titration curves of the different binary systems under investigation, the parameters, $\bar{n}_{\mathrm{A}}, \bar{n}$ and $\mathrm{pL}$ were calculated using the modified formula of Irving and Rossotti ${ }^{(38)}$. The values of the dissociation constants of the ligand used in this work and the metal - ligand stability constants for the binary complex as depicted from the titration curves are given in Table 1 . The stability constants for the binary $\mathrm{Zn}$ - (BCPAP), Cd-(BCPAP) and Ce-(BCPAP) complexes were computed from the titration curves in which the metal- ligand ratio was 1:2. The potentiometric titration graph for the Schiff base 1,4-bis(2`-carboxyphenylazomethine)phenylene (BCPAP) showed an inflection at a $=2$ to form the dianionic species (where a is the number of moles of base added per mole of ligand). The constants $K_{(B C P A P)}^{H}$ and 
$K_{M\left(B C P A P-H_{2}\right)}^{M}$ corresponding to the stepwise dissociation of the ligand are given in Table 1. The titration graph for each system containing 1:2 molar ratio of $\mathrm{Zn}^{2+}, \mathrm{Cd}^{2+}$ or $\mathrm{Ce}^{3+}$ and the Schiff base ligand exhibits a single inflection at $\mathrm{m}=2$ (where $\mathrm{m}$ is the number of moles of base added per mole of metal ion) indicating the formation of mono-binary complexes as shown in Fig. 3. To obtain reliable equilibrium constants from a representative set of data, for all systems at least three independent pairs of titrations curves were recorded for the above acidity constants and the results averaged.

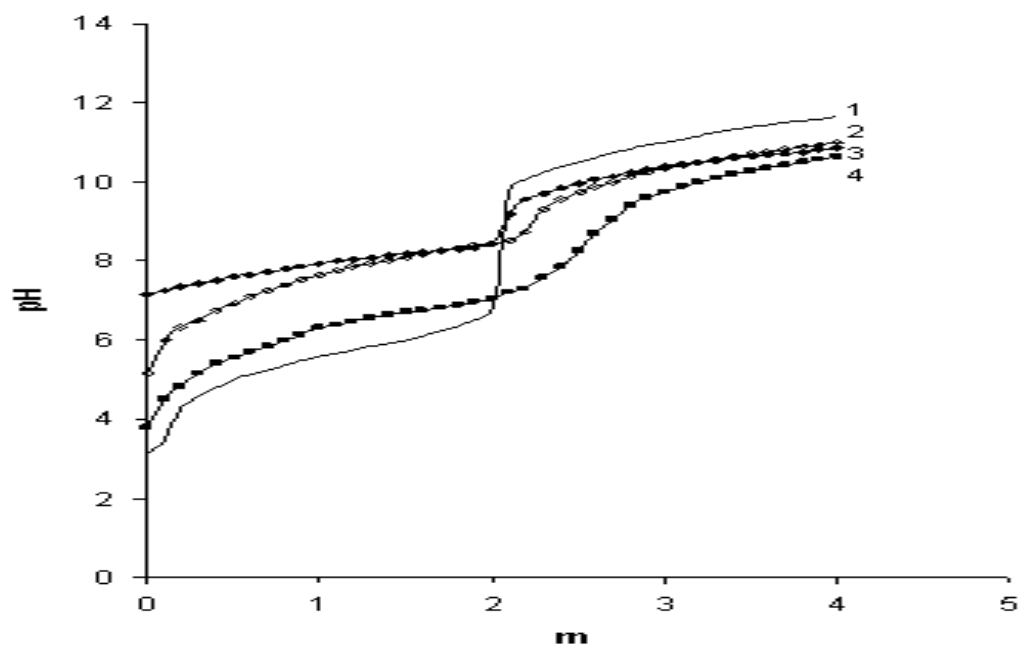

Fig. 3. Potentiometric titration curves of: 1) deprotonated ligand BCPAP, 2) $\mathrm{Zn}(\mathrm{II})$ BCPAP, 3 ) Cd(II)-BCPAP and 4 ) Ce(III)-BCPAP binary systems .

[m $=$ moles of alkali per mole of metal ion].

The abscissa represents the moles of alkali added per mole of ligand.

TABLE 1. Logarithms of stability constants of $\mathrm{Zn}^{2+}, \mathrm{Cd}^{2+}$ and $\mathrm{Ce}^{3+}$ complexes containing 1:2 ratio of metal ion with the Schiff base 1,4-bis (2`-carboxyphenylazomethine)phenylene (BCPAP) [Temp. $25^{\circ} \mathrm{C}, \mathrm{I}=0.1$ $\mathrm{M}\left(\mathrm{KNO}_{3}\right) \mathrm{pK}_{1}$ and $\mathrm{pK}_{2}$ for (BCPAP) are 5.05 and 6,125 , respectively.

\begin{tabular}{|l|c|c|c|}
\hline Metal ion & $\log k_{M L}^{M}$ & $\log k_{M L_{2}}^{M L}$ & $\log \beta_{M L_{2}}^{M L}$ \\
\hline $\mathrm{Zn}(\mathrm{II})$ & 4.825 & 4.550 & 9.375 \\
\hline $\mathrm{Cd}(\mathrm{II})$ & 3.513 & 3.425 & 6.938 \\
\hline $\mathrm{Ce}(\mathrm{III})$ & 4.125 & 4.013 & 8.138 \\
\hline
\end{tabular}

Egypt. J. Chem. 54, No. 5 (2011) 


\section{Characterization of the isolated coordination polymers}

Solubility, viscosity and electrical conductivity

The ability of bis-bidentate (BCPAP) ligand to form coordination polymers was examined by preparing its coordination polymers with divalent transition metal ions $\mathrm{Zn}^{2+}$ and $\mathrm{Cd}^{2+}$ and lanthanide metal ion $\mathrm{Ce}^{3+}$. The coordination polymers vary in colour, as shown in Table 2 and are not softened up to $360^{\circ} \mathrm{C}$ upon heating. They are insoluble in common organic solvents and have high melting point, therefore it is not possible to characterize them by molecular mass using conventional methods like, osmometry..., etc. The metal content estimation of each of coordination polymer by polentiometric study revealed 1:1 metal ligand $(\mathrm{M} / \mathrm{L})$ stoichiometry. This feature is supported by $\mathrm{C}, \mathrm{H}$, and $\mathrm{N}$ contents in the polymers. The molar conductance values of $10^{-3} \mathrm{M}$ of $1: 1$ (M:L) ratio of zinc(II), cadmium(II) and cerium(III)-(BCPAP) in dimethylformamaide (DMF) solution were found 2.62, 2.72 and $2.64 \mathrm{ohm}^{-1} \mathrm{~mol}^{-1} \mathrm{~cm}^{-1}$, respectively. This indicates that all polychelates are insulators. The electrical conductivity of the $\mathrm{Zn}(\mathrm{II}) ; \mathrm{Cd}(\mathrm{II})$ and Ce(III) polymer complexes are $5.62 \times 10^{-11}, 7.79 \times 10^{-11}$ and $8.56 \times 10^{-10} \Omega^{-1} \mathrm{~cm}^{-1}$, respectively. The data reveals that the polymer-metal complexes are very poor electrical conductors. The inherent viscosities of the polymers solutions $(0.5 \% \mathrm{w} / \mathrm{v})$ in DMF were determined at $25^{\circ} \mathrm{C}$. Elemental analysis and physical properties data provide good evidence that the chelates are polymeric in nature and the results of conductivity measurements were collected in Table 2.

TABLE 2. Analytical and characterization data of the ligand BCPAP and its $\mathrm{Zn}(\mathrm{II})$, Cd(II) and Ce(III) polychelates.

\begin{tabular}{|c|c|c|c|c|c|c|c|c|c|}
\hline \multirow{2}{*}{$\begin{array}{c}\text { Chelate } \\
\text { Empirical Formula }\end{array}$} & \multirow{2}{*}{ Colour } & \multirow{2}{*}{$\begin{array}{c}\text { Yield } \\
\%\end{array}$} & \multirow{2}{*}{$\begin{array}{l}\text { M.P } \\
\left({ }^{\circ} \mathbf{C}\right)\end{array}$} & \multicolumn{3}{|c|}{ Found (Calc.) \% } & \multirow{2}{*}{$\begin{array}{l}{ }^{a} \eta \mathbf{m h} \\
\text { (dl/g) }\end{array}$} & \multirow{2}{*}{$\begin{array}{l}\text { Electrical } \\
\text { conductivity } \\
\left(\mathrm{ohm}^{-1} \mathbf{c m}^{-1}\right)\end{array}$} & \multirow{2}{*}{${ }^{\mathrm{b}} \mathrm{M} . \mathrm{W}$. } \\
\hline & & & & C & $\mathbf{N}$ & $\mathbf{H}$ & & & \\
\hline $\mathrm{C}_{22} \mathrm{H}_{16} \mathrm{~N}_{2} \mathrm{O}_{4}$ & Yellow & 92 & 264 & $\begin{array}{l}70.90 \\
70.98\end{array}$ & $\begin{array}{l}4.33 \\
4.30\end{array}$ & $\begin{array}{c}7.56 \\
7.53\end{array}$ & 0.76 & $4.975 \times 10^{-12}$ & 372 \\
\hline$\left[\mathrm{ZnC}_{22} \mathrm{H}_{14} \mathrm{~N}_{2} \mathrm{O}_{4} \cdot \mathrm{H}_{2} \mathrm{O}\right]_{\mathrm{n}}$ & brown & 82 & $>360$ & $\begin{array}{l}58.22 \\
58.19\end{array}$ & $\begin{array}{l}3.53 \\
3.55\end{array}$ & $\begin{array}{l}6.18 \\
6.19\end{array}$ & 0.11 & $6.121 \times 10^{-10}$ & 453.39 \\
\hline$\left[\mathrm{CdC}_{22} \mathrm{H}_{14} \mathrm{~N}_{2} \mathrm{O}_{4} \cdot \mathrm{H}_{2} \mathrm{O}\right]_{\mathrm{n}}$ & $\begin{array}{c}\text { Pale } \\
\text { brown }\end{array}$ & 75 & $>360$ & \begin{tabular}{|l|}
52.76 \\
52.7
\end{tabular} & $\begin{array}{l}3.205 \\
13.505\end{array}$ & $\begin{array}{l}5.60 \\
5.70\end{array}$ & 0.35 & $4.551 \times 10^{-10}$ & 500.41 \\
\hline$\left[\mathrm{CeNO}_{3} \mathrm{C}_{22} \mathrm{H}_{14} \mathrm{~N}_{2} \mathrm{O}_{4} \cdot \mathrm{H}_{2 \mathrm{O}}\right]_{n}$ & $\begin{array}{c}\text { pale } \\
\text { brown }\end{array}$ & 79 & $>360$ & $\begin{array}{l}44.65 \\
44.72\end{array}$ & $\begin{array}{l}2.71 \\
2.70\end{array}$ & $\begin{array}{l}7.02 \\
7.14\end{array}$ & 0.23 & $5.231 \times 10^{-9}$ & 590.15 \\
\hline
\end{tabular}

${ }^{\mathrm{a}} \eta=$ inherent viscosity

${ }^{\mathrm{b}}$ M.W. = molecular weight of repeat unit 
Electronic infrared absorption spectra

The Schiff base (BCPAP) in dioxane was studied in UV and visible region $(250-00 \mathrm{~nm})$. The spectra indicate the presence of an absorption band at wavelength of $318 \mathrm{~nm}$ that shifted to longer wavelength $338 \mathrm{~nm}$ with increasing $\mathrm{pH}$ values. The spectra of $\mathrm{M}$ - BCPAP $1: 1$ molar ratio $\left(2.5 \times 10^{-4} \mathrm{M}\right)$ complex with the reagent as reference in dioxane are characterized by absorption maxima at 420, 442 and $438 \mathrm{~nm}$ for $\mathrm{Zn}(\mathrm{II})$; $\mathrm{Cd}(\mathrm{II})$ and $\mathrm{Ce}(\mathrm{III})$, respectively. On comparing the electronic absorption spectra of the free ligand BCPAP with those of the chelates of $\mathrm{Zn}(\mathrm{II}), \mathrm{Cd}(\mathrm{II})$, $\mathrm{Ce}$ (III) the shift of the ligand spectrum band at $338 \mathrm{~nm}$ to longer wavelength, proved the coordination of the metal ions to the ligand.

The most important IR bands of the bis-bidentate ligand 1,4-bis(2 carboxyphenylazomethine)phenylene (BCPAP) are shown in Fig. 2. The important IR spectral features are a broad band extending from 2630-2500 $\mathrm{cm}^{-1}$, with maximum at $2570 \mathrm{~cm}^{-1}$, attributed to $v_{(\mathrm{OH})}$ carboxylic group. The IR spectrum of the ligand exhibited $v_{(\mathrm{C}=\mathrm{O})}$ carboxylic mode at $1706 \mathrm{~cm}^{-1}$. The band at $1482 \mathrm{~cm}^{-1}$ was attributed to a symmetric stretching vibrations of $\left(\mathrm{COO}^{-}\right)$group. The Schiff base exhibited a strong band at $1615 \mathrm{~cm}^{-1}$, assigned to the azomethine $v_{(\mathrm{C}=\mathrm{N})}$ stretching mode ${ }^{(46)}$. The IR spectra of coordination polymers are shown in Fig. 4 - 6. It is observed that they resemble each other in the general shape while the comparison of IR spectra of parent (BCPAP) with its coordination polymers indicated certain characteristic differences. One of the significant differences expected is the absence of broad band in the $2630-2550 \mathrm{~cm}^{-1}$ due to $v_{(\mathrm{COO})}$ stretching vibration frequency in the case of coordination polymers. The absence of $v_{(\mathrm{OH})}$ of the carboxylic group of the acid ligand confirms the deporotonation of the $\mathrm{COOH}$ group and the participation of oxygen in coordination ${ }^{(47)}$. On the spectrum of the coordination polymers the $v_{\mathrm{s}(\mathrm{COO})}$ ions are shifted to lower frequencies by $16-84 \mathrm{~cm}^{-1}$. The band at $1706 \mathrm{~cm}^{-1}$ which is attributed to $v_{(\mathrm{C}=0)}$ carboxylic mode disappears in the spectrum of $\mathrm{Cd}^{2+}-\mathrm{BCPAP}$ coordination polymer and is observed at 1648 and at $1646 \mathrm{~cm}^{-1}$ in spectrum of $\mathrm{Zn}^{2+}$ and $\mathrm{Ce}^{3+}$ respectively, with a shift towards lower frequency by about $60 \mathrm{~cm}^{-1}$. The other noticeable difference is that the band in the IR spectrum of $\mathrm{BCPAP}$ due to $\mathrm{C}=\mathrm{N}$ stretching at $1615 \mathrm{~cm}^{-1}$ shifted to lower frequency (27- 40) $\mathrm{cm}^{-1}$. The band at $1422 \mathrm{~cm}^{-1}$ in the IR spectrum of BCPAP is assigned to in-plane $\mathrm{OH}$ deformation ${ }^{(48)}$. It is shifted towards higher frequency $\sim\left(1505 \mathrm{~cm}^{-1}\right)$ in the spectra of the coordination polymers, indicating the formation of a metal - oxygen bond. The IR spectra of the three polymeric complexes show that they possess coordinated water. The presence of $\mathrm{H}-\mathrm{O}-\mathrm{H}$ rocking vibration due to coordination water molecules appears at $834-812 \mathrm{~cm}^{-1(49)}$. The presence of water can be also detected by the characteristic band in $3475-3289 \mathrm{~cm}^{-1}$ region in IR spectrum of the coordination polymers.

Egypt. J. Chem. 54, No. 5 (2011) 


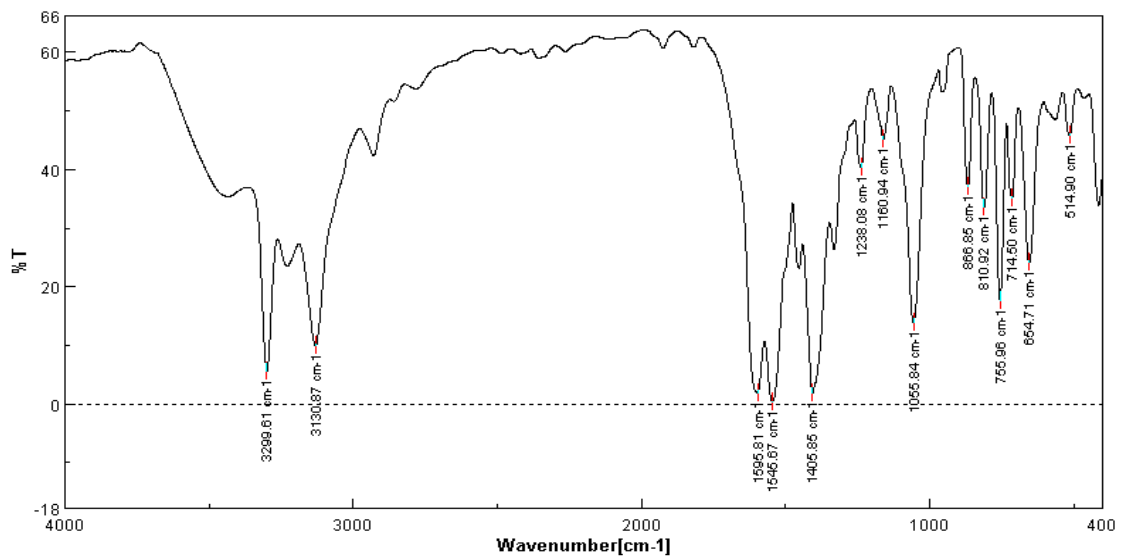

Fig. 4. FTIR spectrum of coordination polymer Zn-BCPAP .

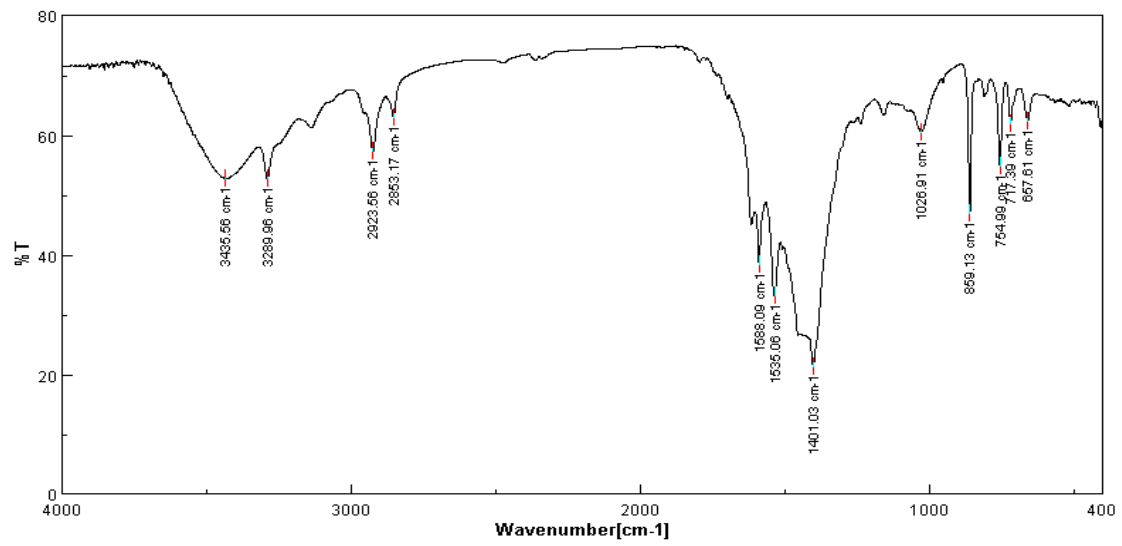

Fig. 5. FTIR spectrum of coordination polymer Cd-BCPAP .

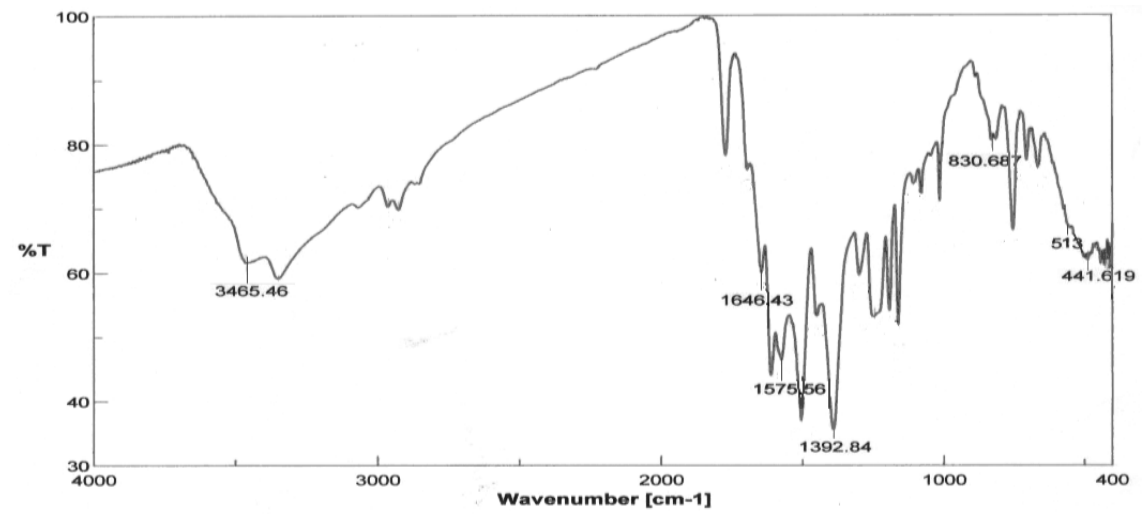

Fig. 6. FTIR spectrum of coordination polymer Ce-BCPAP . 
Thermal Analysis Data

The thermal behaviour of the parent BCPAP polymer and its metal chelates $\mathrm{Zn}(\mathrm{BCPAP}), \mathrm{Cd}(\mathrm{BCPAP})$ and $\mathrm{Ce}(\mathrm{BCPAP})$ were investigated by performing thermogravimetric analysis (TG) and using differential scanning colorimetry (DSC). Fig. 7\&8 show the TG and DSC data and the weight loss of all samples at different temperatures. Thermogravimetry of the coordination polymers reveals the variation of thermal stability by complexation with metal ions. The weight loss of the polymer samples at different temperatures indicated that the degradation of the parent ligand BCPAP is noticeable beyond $200^{\circ} \mathrm{C}$. The thermogram characteristic of the ligand has two decomposition steps at $200^{\circ} \mathrm{C}$ and $380^{\circ} \mathrm{C}$. The first decomposition step is corresponding to the elimination of two molecules of benzoic acid with carboxylic oxygen. The second step is in the region 380$580^{\circ} \mathrm{C}$. The weight loss in this temperature range can be ascribed to the removal of the residual from ligand molecule. The obtained TG analysis curves of the different synthesized coordination polymers displayed the removal of one coordinated water molecule. The TG curve characteristic of $\mathrm{Zn}$ (BCPAP) has two steep decomposition steps at $120^{\circ} \mathrm{C}$ and $350^{\circ} \mathrm{C}$. The complex starts by showing significant mass loss at $375^{\circ} \mathrm{C}$ giving zinc oxide as stable end product up to $600^{\circ} \mathrm{C}$. Such a thermogravimetric behaviour indicates the presence of water molecule on the coordinated polymeric sample. Simillary, the decomposition steps are observed in the TG of CdBCPAP. The first- stage decomposition is the major decomposition step, in which the chain breaks and the rupture could be identified to correspond to elimination of the parent ligand. In the last step, coordination polymer of $\mathrm{Cd}^{2+}$ decomposes giving a metal oxide residue. The coordination polymer of $\mathrm{Ce}^{3+}$ undergoes gradual decomposition, with weight losses steps at different temperature zones and finally gives the oxide $\mathrm{CeO}_{2}$ as a stable product up to $750^{\circ} \mathrm{C}$ which was examined by Infrared. The obtained TG curve shows that the weight loss corresponding to the first step can be attributed to absorbed water molecule. The second stage at $140-200^{\circ} \mathrm{C}$ can be considered as due to the removal of one coordinated water molecule. Over the temperature $200^{\circ} \mathrm{C}$ the two steep steps can be interpreted as due to the removal of the Schiff base coordinated ligand. In the last decomposition step at $570^{\circ} \mathrm{C}$, the weight loss can be attributed to the removal of $\mathrm{NO}_{2}$ molecule of nitrate group.

\section{Scanning electron microscopy (SEM)}

The analytical results indicate that the synthesized coordination polymers posses the general formulas $\left\{\mathrm{Zn}(\mathrm{BCPAP})\left(\mathrm{H}_{2} \mathrm{O}\right)\right\} \mathrm{n},\left\{\mathrm{Cd}(\mathrm{BCPAP})\left(\mathrm{H}_{2} \mathrm{O}\right)\right\} \mathrm{n}$ and $\left\{\mathrm{Ce}(\mathrm{BCPAP})\left(\mathrm{NO}_{3}\right)\left(\mathrm{H}_{2} \mathrm{O}\right)\right\} \mathrm{n}$. The structural studies of these polymeric complexes are also supported by scanning electron microscopy (SEM) as shown in Fig. 9-11.

Egypt. J. Chem. 54, No. 5 (2011) 


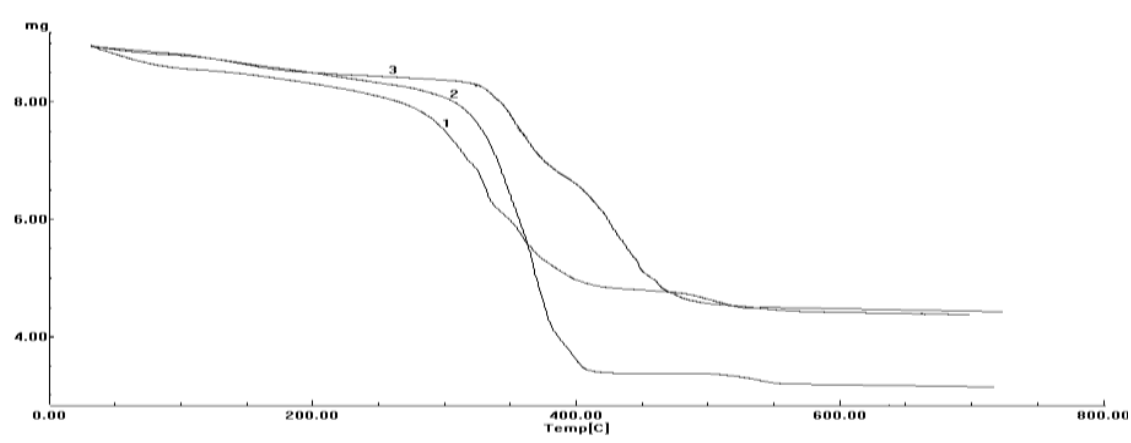

Fig. 7. Thermal analysis (TG curves) for the metal ion complexes of Schiff base BCPAP: 1, Ce- BCPAP; 2, Cd-BCPAP; 3, Zn-BCPAP.

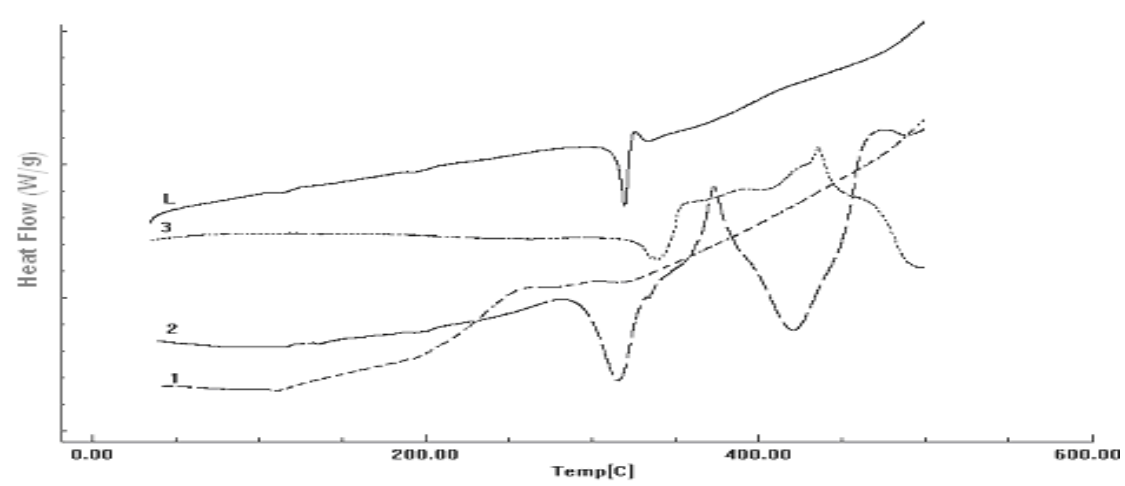

Fig. 8. DSC thermodiagram of Ligand BCPAP (L), Ce-BCPAP (1), Cd-BCPAP (2) and Zn-BCPAP (3).

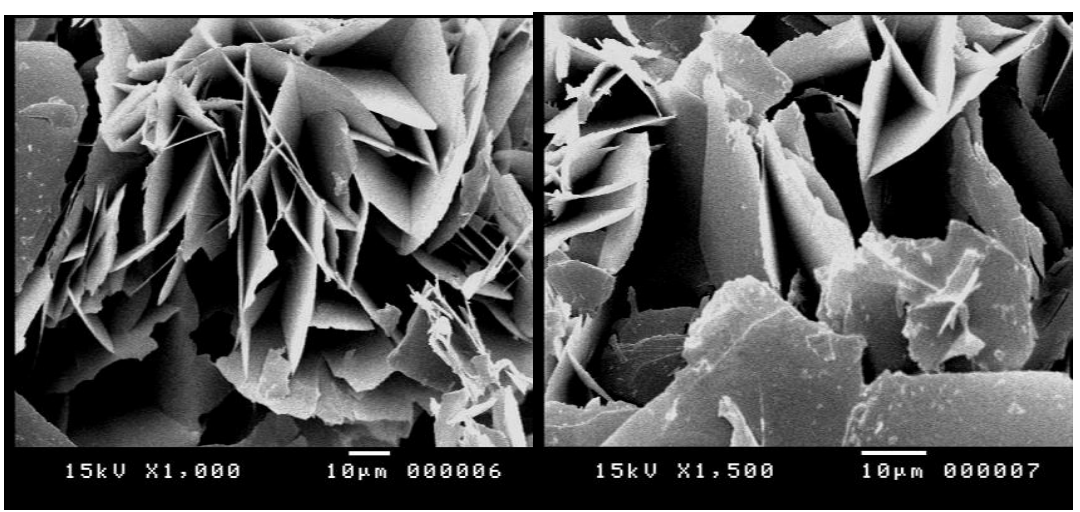

(A)

(B)

Fig. 9. SEM micrograph of $(\mathrm{Zn}-\mathrm{BCPAP})_{\mathrm{n}}$ coordination polymer film: A) electrode side, magnification 1000x, B) electrode side, magnification 1500x. 


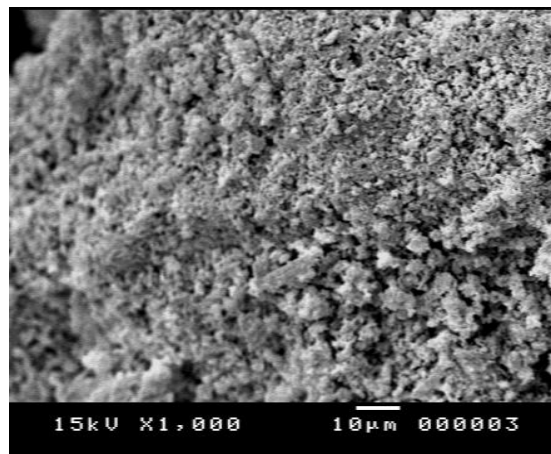

(A)

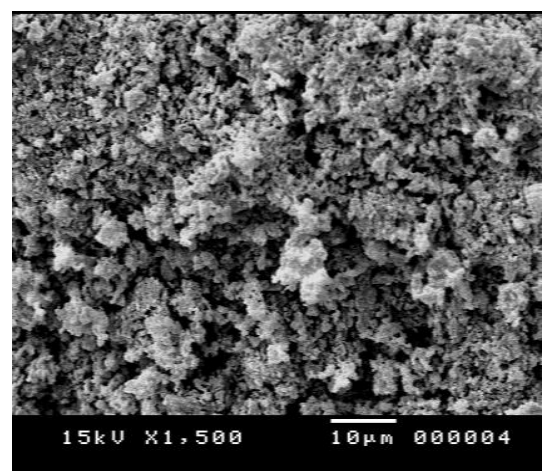

(B)

Fig. 10. SEM micrograph of (Cd-BCPAP $)_{n}$ coordination polymer film: A) electrode side, magnification 1000x, B) electrode side, magnification 1500x.

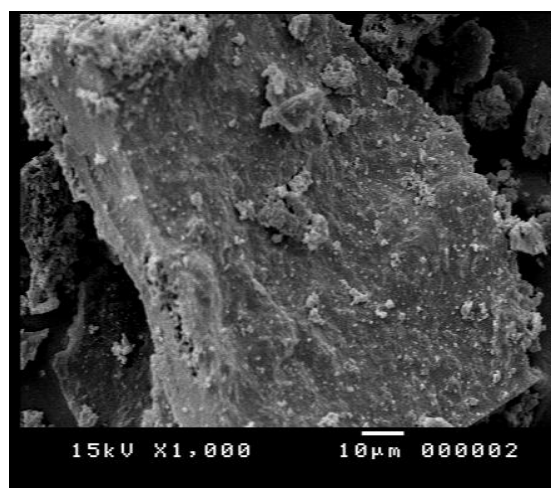

(A)

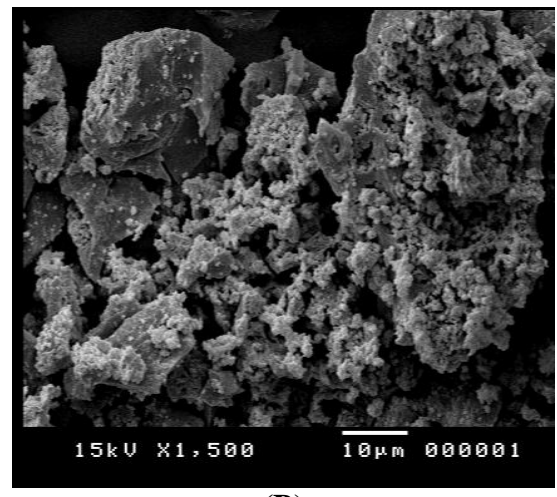

(B)

Fig. 11. SEM micrograph of $(\mathrm{Ce}-\mathrm{BCPAP})_{\mathrm{n}}$ coordination polymer film: $\left.=\mathrm{A}\right)$ electrode side, magnification 1000x, B) electrode side, magnification 1500x.

\section{Conclusions}

As a result of the study, new three coordination polymers were prepared by reacting the bis-bidentate ligand (1,4-bis(2`-carboxyphenylazomethine) phenylene) BCPAP with $\mathrm{Zn}^{2+}, \mathrm{Cd}^{2+}$ and $\mathrm{Ce}^{3+}$ ions. The formation of the complexes is found to be dependent on the $\mathrm{pH}$ of the solution. The dissociation constants of the ligand BCPAP, the stepwise stability constants, stoichiometry and the optimal $\mathrm{pH}$ conditions for preparing the chelates were determined from potentiometric data. The metal contents in all complexes are found to be consistent with 1:1 metal: ligand. Only homo-coordination polymers were found. The electrode side conductivity of the polychelates are in the range $5.62 \times 10^{-11}$ - and $8.56 \times 10^{-10} \Omega^{-1} \mathrm{~cm}^{-1}$, indicating that all the present polychelates are insulators. 


\section{References}

1. Jian X., Xiao, L., Zhow, W. and Xu, F., Polym. Bull. 63, 225 (2009).

2. Mariano, R.M., Oliverap, M.R.L., Rubiyger, M.M.M. and Vscante L.L.Y., Eur. Polym. J. 43, 4706 (2007).

3. Demirbas, U., Kurt, A., Sennaroglu A., Yilgőr, E. and Yilgor I., Polymer, 47 , 982 (2006).

4. Grimes, S. M., Polym. Degrad. Stab. 91, 3274 (2006).

5. Arimato, F. S. and Haven, A.C., J. Am. Chem. Soc. 77, 6295 (1955).

6. Dragutan, V., Dragutan, I. and Fischer, H., J. Inorg. Organomet. Polym. 18, 18 (2008).

7. Geckeler, K., Weingartner, K. and Bayer, E., Pure Appl. Chem. 52, 1883 (1980).

8. Efendiev, A.A. and Kabanov, V. A., Pure Appl. Chem. 54, 2077 (1980).

9. Wolf, P. and Mallon, H. J., Acta Hydrochim. Hydrobiol. 9, 467 (1981).

10. Hughes, M.N., "The Inorganic Chemistry of Biological Processes"; p. 416 Wiley, New York, (1981).

11. "Metal Ions in Biological System", Marcel Dekker, New York, P. 168 (1981).

12. Williams, D.R., "The Metals of Life", p. 236 Van Norstrand Reinhold, Princeton, New Jersey, (1971).

13. Lettimer, R. L. and Kroenke, W. J., J. Appl. Polym. Sci. 26, 1191 (1981).

14. Patel, M. N. and Jani, B. M., J. Macromol. Sci. Chem. A22, 1517 (1985).

15. Patel, R.D., Patel H. S. and Patel S. R., Eur. Polym. J. 23, 229 (1987).

16. Patel, N.H., Patel, K.N. and Patel, M.N., Synth. React. Inorg. Met. Org. 31 (6), 1031 (2001).

17. Patel, N.H., Patel, K.N., Patel, K.M. and Patel, M.N., Synth. React. 32(10), 1879 (2002).

18. Jứnior, G.C., Silva, A.P.S. and Guinesi, L.S., Polyhedron, 23. 1923 (2004).

19. Abd-El-Aziz, A.S., Macromol. Rapid. Commun.23, 995 (2002).

20. Abd-El-Aziz, A.S. and Todd, E. K., Coord. Chem. Rev. 246, 3 (2003).

21. Abd-El-Aziz, A.S., Okasha, R.M. and Afifi, T.H., J. Inorg. Organomet. Polym. Mater. 4, 269 (2004). 
22. Abd-El-Aziz, A.S. and Manners I., J. Inorg. Organomet. Polym. Mater. 15, 157 (2005).

23. Abd-El-Aziz, A.S., Sarruthers, S.A., Aguiar, P.M., and Kroeker, S., J. Inorg. Organomet. Polym. Mater. 15, 349 (2005).

24. Puddephatt, R.J., J. Inorg. Organomet. Polym. Mater. 15, 371 (2005).

25. Wolf, M.O., J. Inorg. Organomet. Polym. Mater. 16, 189 (2004).

26. Wong, W. Y., Coord. Chem. Rev. 249, 971 (2005).

27. Kaliyappan, T. and Kannan, P., Prog. Polym. Sci. 25, 343 (2000).

28. Methenitis, C., Morcellt, J., Pneumatikakis, G. and Morcellt, M., Eur. Polym. J. 39, 687 (2003).

29. Roma-Luciow, L., Sarraf, L. and Morcellt, M., Eur. Polym. J. 37, 1741 (2001).

30. Santana, A.L., Noda, L.K., Pires, A.T.N. and Bertolino, J.R., Polym. Test. 23, 839 (2004).

31. Watanabe, A., Miyashita, T., Kasuya, A., Takahashi, M. and Kawazoe, Y., Polymer, 49, 554 (2008).

32. Li, B., Zhu, X., Zhou, J., Peng, Y. and Zhang, Y., Polyhedron, 23, 3133 (2004).

33. Kuo, P., Liang, W. and Chen, T., Polymer, 44, 2957 (2003).

34. Mun, G.A., Nurkeeva, Z.S., Khutoryanskiy, V.V. Sarybayeva, G.S. and Dubolazov, A. V., Eur. Poym. J. 39, 1687 (2003).

35. Sebastian, N., Gerge, B. and Mathew, B., Polym. Degrade. Stab. 60, 371 (1998).

36. Moustafa, M. H., Bull. Environ. Res. Assiut Univ. 8(1), 103 (2005).

37. Abd-Elmottaleb, M., El-Sayed, A. Y. and Moustafa, M. H., Egypt J. Chem. 38(2), 195 (1995).

38. Irving, H. and Rossotti, H. S., J. Chem. Soc. 2904 (1954).

39. Singh, B., Banerjie, V., Agarwala, B. V. and Dey, A. K., J. Ind. Chem Soc. 57, 365 (1980).

40. Meites, L., "Handbook of Analytical Chemistry" McGraw-Hill, New York (1963).

41. Douheret, G., Bull. Soc. Chim. Fr., 3122 (1968).

42. Gans, P., Sabatini, A. and Vacca, A., J. Chem. Soc. Dalton Trans. 1195 (1985).

43. Moustafa, M. H., Al-Azhar Bull. Sci. 12(2), 295 (2010).

Egypt. J. Chem. 54, No. 5 (2011) 
44. Moustafa, M. H., Al-Azhar Bull. Sci. (AISC'08), 71. (March, 2008),

45. Moustafa, M. H., Assiut Univ. Bull. Environ. Res. 13 (2), 77 (2010).

46. Sebastian, N., Gerge, B. and Mathew, B., Polym. Degrade. Stab. 60, 371, (1998).

47. Young, R. P., J. Hetrocycl. Chem. 9, 271, (1972).

48. Charles, R.G, Freiser, H., Priedel, R., Hilliand, L.E. and Johnston, R.D., Spectrochim. Acta, 8, 1, (1958).

49. Brzyka, W., Rzaczynska, Z. and Kula, A., Monat. Chem. 120, 211 (1989).

(Received 8/6/2011; accepted $11 / 4 / 2012)$ 


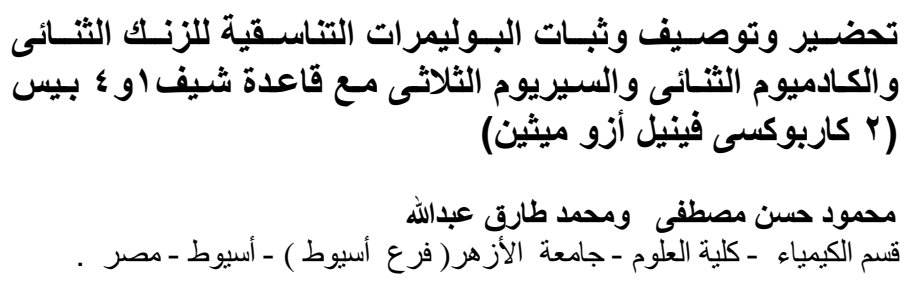

تم فى هذا البحث تحضير قاعدة شيف (، إك - بيس (- r-هيدروكسى فينيل أزو ميثين )

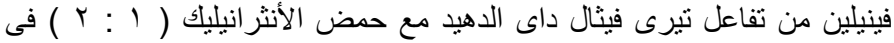

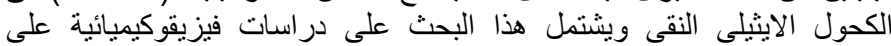

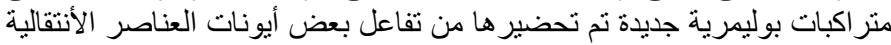
وهي ميل Cd

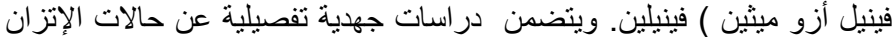

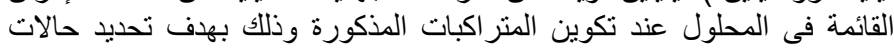

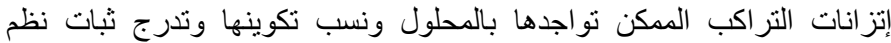

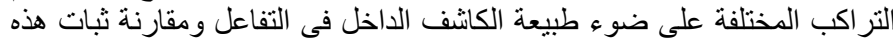

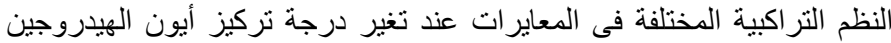

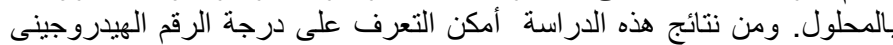

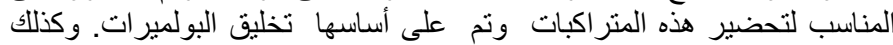

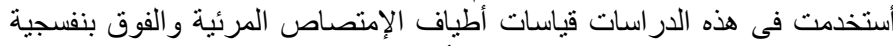

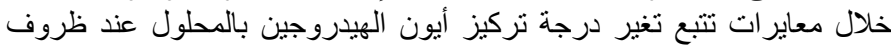

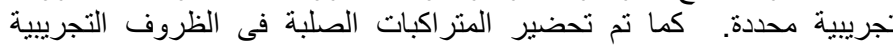

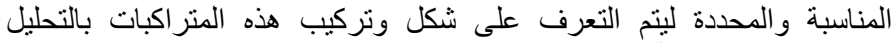

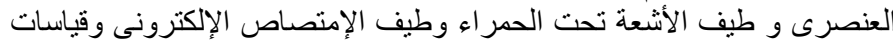

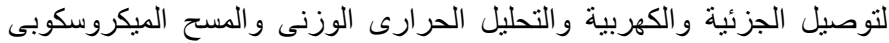

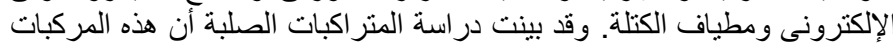
هى سلاسل بوليمر ات تناسقية. 